\title{
Petrographic Study of the Sandstones of Eze-Aku Formation (Turonian) in Abaomege, Southern Benue Trough, Nigeria.
}

\author{
E. O. Igwe, E. N. Edene, P. N. Obasi \\ Department of Geology and Exploration Geophysics, Ebonyi State University, P.M.B., 053, Abakaliki, Nigeria.
}

\begin{abstract}
The Turonian Eze-Aku Formation in the study area uncomformably overlies the Albian Asu-River Group and unconformably underlies the Nkporo Group (Campano-Maastrichtian) in Afikpo Synclinorium. The petrographic study of the sandstones in Abaomege was carried out to determine the provenance, paleoclimate and source area tectonics for the sandstone facies. The lithofacies encountered in the area consist of fine to medium grained calcareous sandstones which correlate the sediments of Turonian Amasiri Sandstone and alternating sequence of light grey to dark grey shales, and siltstone. Petrographic analysis of the sandstone suggests that they are mineralogically mature and are essentially quartz arenites. Analysis and interpretation of sedimentary structures, mostly the cross beds, and also the structures of quartz grains indicates that the sandstones were derived primarily from granitic Basement Complex rocks from the Oban Massif, under humid climate. The paleocurrent plots for the sandstones show bimodal distribution pattern, suggesting a shore environment of deposition.
\end{abstract}

Keywords: Eze-Aku Formation, sandstones, paleocurrent, provenance, petrography.

\section{Introduction}

The sandstones in Abaomege area are part of the sediments of the Late Cenomanian-Turonian Eze-Aku Formation of the Middle Cretaceous which outcrops at eastern flank of the Abakaliki Anticlinorium, Southern Benue Trough Nigeria. There has not been enough work done to establish the provenance regions, paleoclimatic setting and source area tectonics for the sandstones of Eze-Aku Formation in Abaomege area, southern Benue Nigeria. This study seeks to carry the petrography study and paleocurrent analysis of the sandstone and its implications on the provenance, sediment direction flow and paleoclimatic setting. [1] established an unconformity between the Turonian Eze-Aku Formation and the Campanian - Maastrichtian Nkporo Formation in the Afikpo Synclinorium. [2] reviewed the stratigraphy of the Eastern Nigeria, although some of the original names he adopted have been changed by ([3]; [4]) in their later work. According to their report on tectonic activities, which occurred during the Cretaceous period, resulted in a series of folds in the sequence of the Asu River Group, the Eze - Aku Formation and created the Abakaliki Anticlinorium. Regional study of Pre Santonian sandstones including the sandstones of the study carried out by ([5]; [6]); they suggested that the sandstones are petrologically arkosic quartz arenites derived from the granitic/metamorphic basement rocks. An interest in paleocurrent analysis can be noted in the work of [7] which suggested that since cross bedding of any scale has paleocurrent value, all that is required is that its orientation be systematically measured and mapped. Paleocurrent indicators are orientated sedimentary structures interpreted to have been deposited by ancient flows. Cross beds slip face, pebble imbrications, parting lineation, tool marks and groove casts, and ripple crest orientation are all examples of possible paleocurrent indicators [8]. Some paleocurrent indicators are unidirectional - that is, their shape provides unique information about the direction of the ancient paleoflow. [9] studied the Amasiri Sandstones in the Abaomege, Akpoha and Afikpo areas and noted that the sediment were derived from east of the study area and were deposited as tidal sand ridges in shallow marine environments. The Eze-Aku Formation outcrops out on both sides of the Asu River Group (Fig. 1). It is composed of calcareous shale, siltstone and thin sandy or shelly limestone as well as calcareous fine to medium grained sandstones [3].

The Eze-Aku Formation has been dated to be generally of Lower Turonian age on the basis of diagnostic ammonites and microfauna [3]. Cenomanian forams have also been recovered from the formation. It has an estimated thicknesss of 2100m [10]. Table 1 shows the stratigraphic position of the Eze-Aku Formation in the southeastern Nigeria. Based on the study, the sandstones were suggested to be quartz arenites and the sediments were derived from the Basement Complex rocks of Oban Massif in a humid climate. 

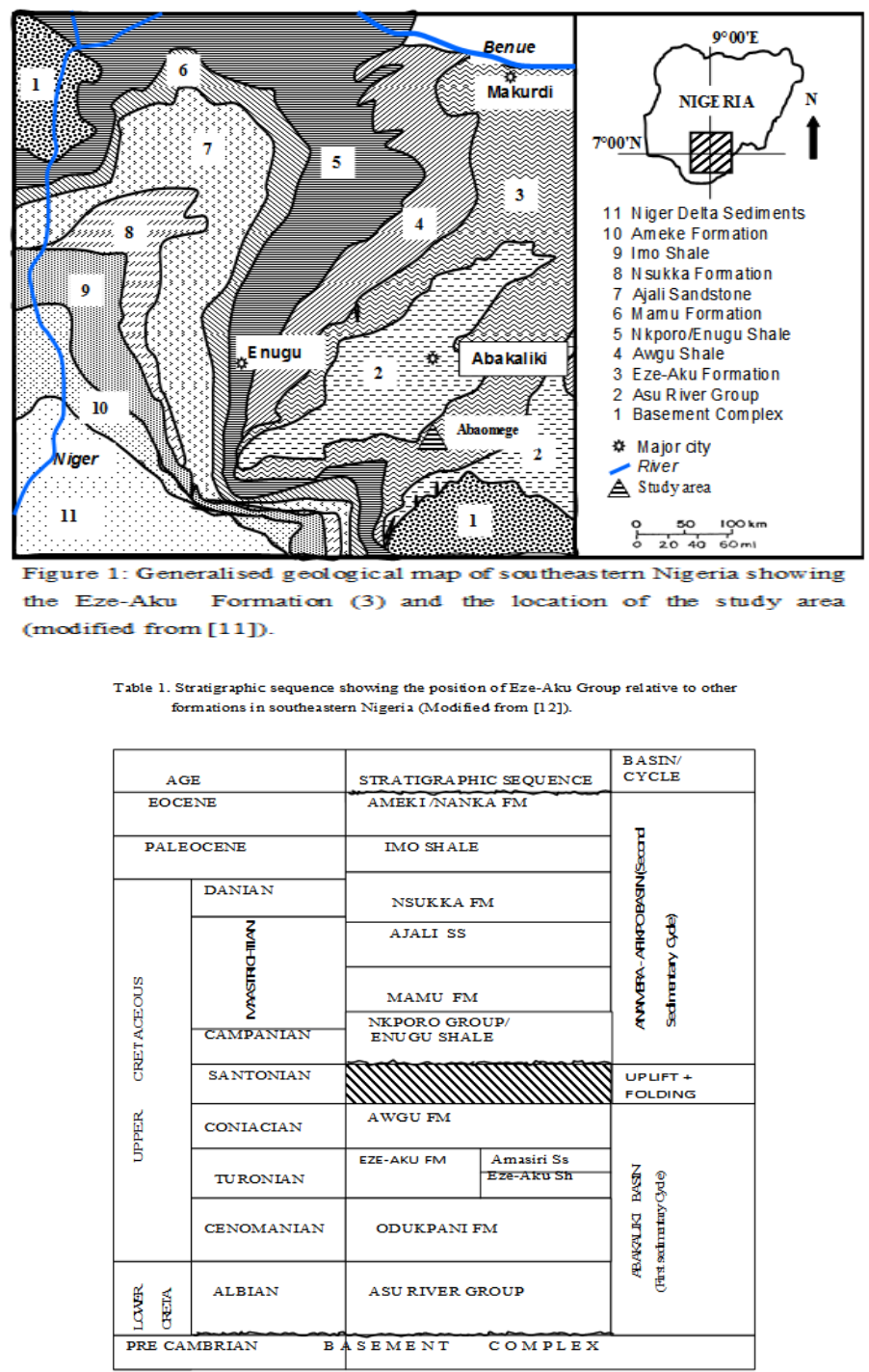

\section{Method Of Study}

The sandstones outcropping in Abaomege area were studied and described. Seven thin sections were prepared from the collected representative sandstone samples. The produced thin section slides were studied using petrographic microscope for minerals identification and the photomicrographs (Figs. 2, $3 \&$ 4), the modal composition (Table 2) and the recalculated modal analysis data (Table 3) generated. Petrographic classification was done using quartz $(\mathrm{Q})$, feldspar $(\mathrm{F})$ and rock fragment $(\mathrm{RF})$, after [8]. The mineral maturity calculated using the mineralogical maturity index (IMM) of [13]. Paleocurrent measurements were acquired from tilted beds and restored to paleo horizontal for both cross bed dip magnitude and direction for the true paleo flow azimuth. Current Rose diagram were constructed based on the data collected from the exposures of the sandstone facies. The interpretation of paleo-flow direction was made directly from the Rose diagrams.

\subsection{Lithostratigraphy}

\section{Results And Discussion}

The lithologic successions in the study area consist of sandstones and shales and were broadly grouped into two lithostratigraphic units based of their lithology, structure and stratigraphic position: Isinkwo-Enyim Sandstone/shale and Abaomege Sandstone units.

The Isinkwo-Enyim Sandstone/shale unit display alternating sequence of sandstone occurring in ridges and low-lying lands represent the shales with sharp contacts. The shale was mapped at Okwurike along the road leading to their market. It is dark grey to black shale, rich in organic matter, highly fissile, parallel laminated with surbordinate carbonaceous mudstones that contain plant remains. This shale which could be blocky or flaggy depending on the mineralogy is composed of clay size grains of quartz, gypsum and mica. At Okwerike, the shale trends $59^{\circ} \mathrm{NE}$ direction and dip is about $38^{\circ}$ to the southeast. The sandstone facies comprises the outcrops exposed at Abaomege, Okwerike, Isinkwo, Enyim and Nsubba. The lithofacies consists dominantly of 
medium grain but may sometimes vary to fine grain and coarse grained sandstones. It is grayish - white in colour on fresh surfaces but brownish in weathered parts.

The Abaomege sandstone unit consists dominantly of medium grained sandstone, but may vary from fine to coarse. It is grayish- white in colour with some brown colouration due to ferruginization. The sandstones occur mainly on the ridges and are consolidated, stratified and cemented with clay, iron oxide and calcite.

\section{2 Petrography}

The petrographic analyses of the sandstones show that quartz, feldspars and mica as framework elements. The cement is composed of clay, iron oxide and calcite while the matrix is composed mainly of unrecystallized clay and silt - size quartz (Table 2). The monocrystalline quartz constitutes $94 \%$ of total quartz while polycrystalline quartz is about $6 \%$ (Fig. 4). The sandstones of Abaomege can be classified as quartz arenite ([14]; [8]) (Fig. 5). The sandstone is dominantly medium grained. The grain shapes range mainly from sub-angular to sub-rounded and rarely angular (Figs. $2,3 \& 4$ ). The sandstones are moderately sorted. The grains show point and line contact. The quartz is essentially monocrystalline with little polycrystalline quartz. Some of the quartz are fractured which indicate some tectonic activities. The degree of textural maturity has been deduced based on the percentages of matrix content $(<5 \%>)$ (Table 2) moderate sorting, poor roundness. All indicate that the sandstone is texturally immature ([15]; [16]). The matrix is composed mainly of unrecystallised clay and silt size quartz acting as subordinate binder to the grains

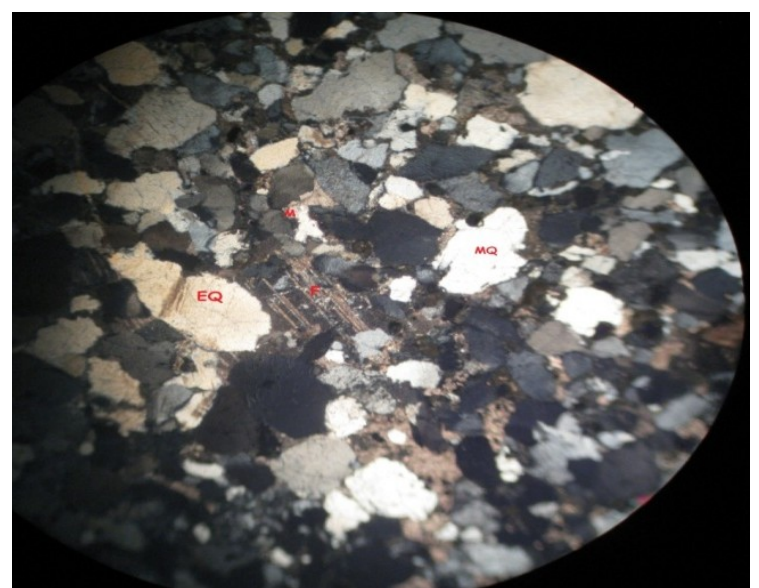

Figure 2: Photomicrograph of sample EO1 under XPL, showing feldspar (F) and monocrystalline quartz (MQ).

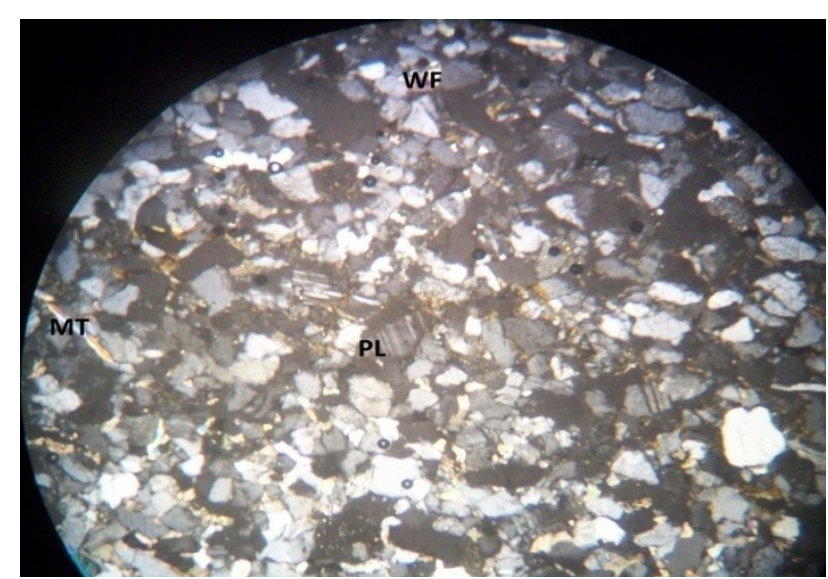

Figure 3: Photomicrograph of sample EO5 showing fresh plagioclase (PL) and weathered feldspar (WF), strained muscovite grains (MT). 

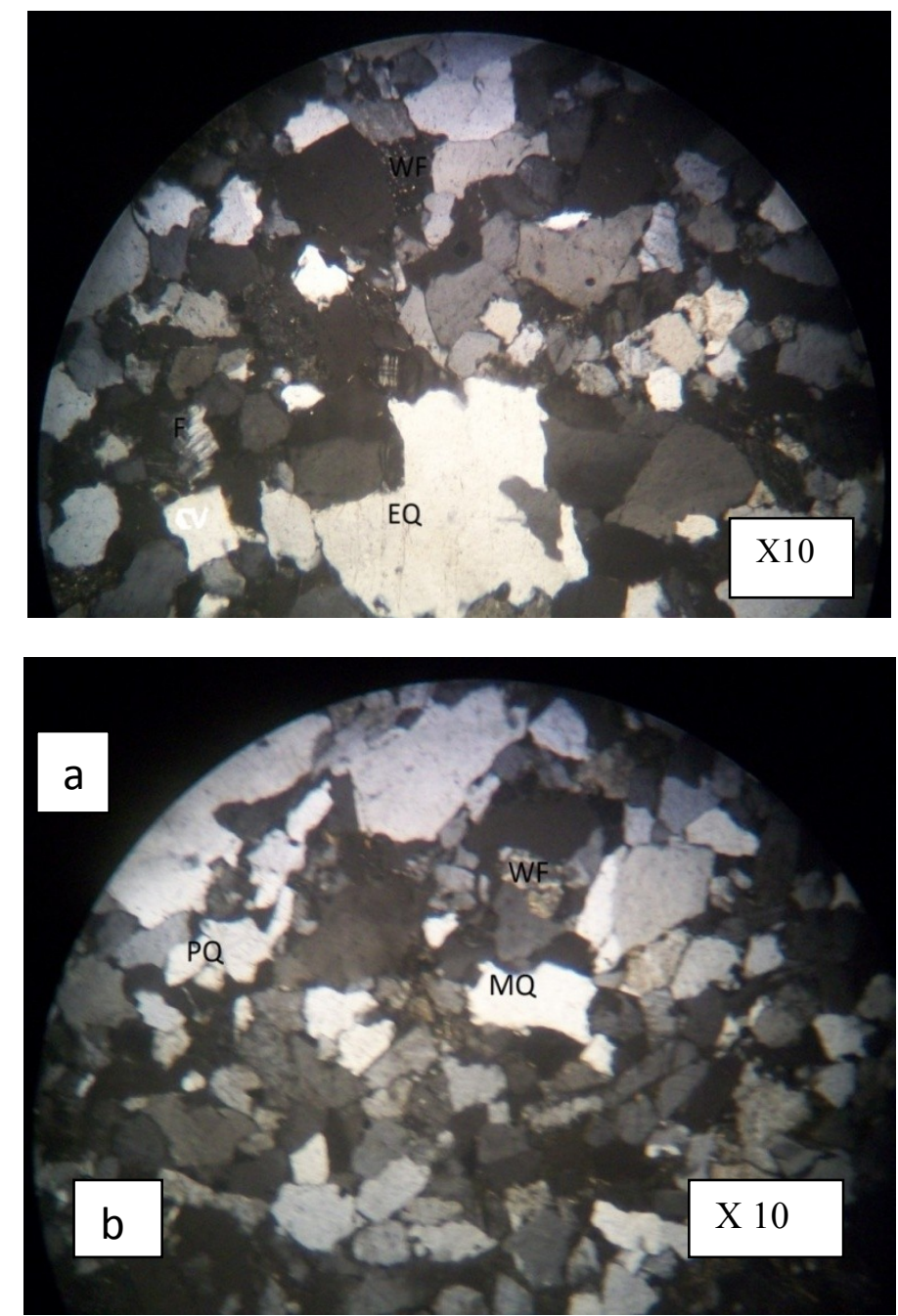

Figure 4: a \& b: Photomicrograph of Sample E09 (top) and E011 (bottom): Medium grained sandstone under XPL with angular to subangular, showing weathered feldspar (WF), polycrystalline grain (PQ), elongate quartz grain (EQ) and monocrystalline grain (MQ)

Table 2: Total composition of the sandstones in Abaomege (\%)

\begin{tabular}{|l|l|l|l|l|l|l|l|l|}
\hline Sample Nos & EO1 & EO3 & EO5 & EO6 & EO7 & EO9 & EO11 & $\begin{array}{l}\text { Average } \\
\text { Value }\end{array}$ \\
\hline Quartz & 61 & 64 & 62 & 68 & 78 & 88 & 69 & 70.00 \\
\hline Feldspar & 1 & 4 & 2 & 3 & 2 & 1 & 3 & 2.28 \\
\hline Rock Fragment & 3 & 2 & 2 & 5 & 6 & 4 & 1 & 3.28 \\
\hline Cement & 15 & 12 & 20 & 18 & 10 & 4 & 18 & 13.85 \\
\hline Matrix & 4 & 6 & 8 & 4 & 3 & 2 & 7 & 4.85 \\
\hline Unfilled voids & 16 & 12 & 6 & 2 & 1 & 1 & 2 & 5.71 \\
\hline total & 100 & 100 & 100 & 100 & 100 & 100 & 100 & 100 \\
\hline
\end{tabular}

Table 3: Framework Composition of the sandstones in Abaomege

\begin{tabular}{|c|c|c|c|c|}
\hline Sample Nos & Quartz & Feldspar & Rock fragment & Total \\
\hline EO1 & प्र4 & $L_{2}$ & 4 & 100 \\
\hline $\mathrm{EO} 3$ & 91 & 6 & 3 & 100 \\
\hline EO5 & 94 & 3 & 3 & 100 \\
\hline EO6 & 90 & 4 & 6 & 100 \\
\hline EO7 & 91 & 2 & 7 & 100 \\
\hline EO9 & 95 & 1 & 4 & 100 \\
\hline EO11 & 94 & 4 & 2 & 100 \\
\hline Average value & 93 & 3 & 4 & 100 \\
\hline
\end{tabular}


The cement is composed of clay, iron oxide and calcite while the matrix is composed mainly of unrecrystallized clay and silt-size quartz. The monocrystalline quartz constitutes $94 \%$ of total quartz while polycrystalline quartz consists of $6 \%$. The sandstone of Eze-Aku Formation can be classified as quartz arenite ([14]; [8]) (Fig. 5)

\subsubsection{Mineralogical maturity}

The mineralogical maturity is deduced using the mineralogical maturity index (MMI) of [13] where

$\mathrm{MMI}=\quad$ Proportion of $\mathrm{Q}$

Proportion of $\mathrm{F}+$ proportion of R.F

Quartz $(\mathrm{Q})=93$, Feldspar $(\mathrm{F})=3$, Rock fragment (R.F) $=4$ (Table 3).
$\mathrm{MMI}=$
$\frac{93}{3+4}$
93
13.28

Since MMI value is $>9$ but less than 19 ; the rock is said to be mineralogically mature [13].

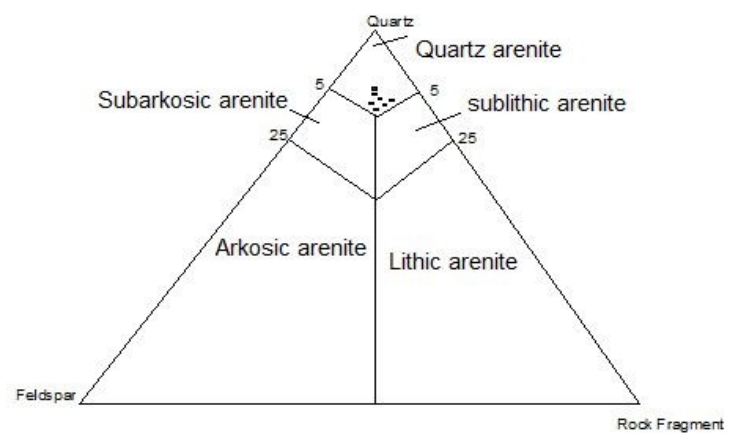

Figure 5: Classification of sandstones of Eze-Aku Formation in Abaomege using Pettijohn (1975)

Table 4: Maturity scale of the sandstones using [13]

\begin{tabular}{|l|l|}
\hline Limiting $\% \mathrm{Q}$ and $(\mathrm{F}+\mathrm{R} . \mathrm{F})$ & $\mathrm{MI}$ and maturity stage \\
\hline $\mathrm{Q}=\geq 95 \%(\mathrm{~F}+\mathrm{R} . \mathrm{F})=5-10 \%$ & $\mathrm{MI}=\geq 19$ super mature \\
\hline $\mathrm{Q}=95-90((\mathrm{~F}+\mathrm{R} . \mathrm{F})=5-10 \%)$ & $\mathrm{MI}=19-9.0$ mature \\
\hline $\mathrm{Q}=90-75 \%(\mathrm{~F}+\mathrm{R} . \mathrm{F})=1025 \%$ & $\mathrm{MI}=9.0-3.0$ sub mature \\
\hline $\mathrm{Q}=75-50 \%(\mathrm{~F}+\mathrm{R} . \mathrm{F})=25-50 \%$ & $\mathrm{MI}=3.0-1.0$ Immature \\
\hline $\mathrm{Q}=<50 \%$ & $\mathrm{MI} \leq 1$ \\
\hline$(\mathrm{F}+\mathrm{R} . \mathrm{F})>50 \%$ & Extremely Immature \\
\hline
\end{tabular}

\section{3 Provenance Evaluation}

The petrography of the sandstones gives clues for the identification of the source rocks. The abundance of monocrystalline quartz indicates plutonic rather than supracrustal parentages (14). The occurrence of only few percentage of polycrystalline quartz in the sandstones suggests a high instability index ([17]; [12] observed that sandstone facies of the first sedimentary cycle (Albian - Santonian) were feldspathic while those of the second cycle (Campanian - Eocene) were quartz arenites. However, the sandstones are of Turonian age (PreSantonian) and are composed of sub-angular grains which may be an indicator of short distance transport.

Consequently, the low content of feldspar in these sandstone facies could be attributed to transport through a high relief, but high intensity of agitation during deposition and very intense chemical and mechanical weathering which depleted the feldspar probably within the basin of deposition. Moreover, in a shore environment there is always a to and fro movement of the sand by waves and currents that are depositing them before they are finally covered by other sediments. In the light of the fore-going it may be suggested that the sand grains may have been derived from the nearby Cameroon Basement Complex and the Oban Massif.

\section{4 Paleoclimate and Source Area Tectonics}

The framework composition and structures of quartz are of paramount importance in paleoclimate interpretation. The key indicator of paleoclimate for sandstones is detrital feldspar [18]. The presence of a significant proportion of feldspars in sandstone may imply a very arid or cold climate in the source regions. The very low incidence of feldspars and rock fragments in these sandstones suggest that they are derived and deposited under humid and warm climate or that they were transported for considerable long distance over a terrain of relatively low relief. The poor roundness of the grains precludes long transport and low relief. 
Feldspar and lithic fragments are generally more susceptible to chemical weathering than to mechanical weathering [19].

They are therefore destroyed much faster in humid and hot climate even under short transportation and high relief. Consequently, the low content of feldspar inn this sandstone unit could be attributed to:

(a) High intensity of agitation during deposition and very intense chemical and mechanically weathering which depleted the feldspar probably within the basing of deposition.

(b) Source and depositional area are of high chemical activity accelerated by high humidity in both areas. A bivariate plot of the ratio $\mathrm{f}$ polycrystalline quartz to feldspar plus lithic fragment against the ratio of total quartz to feldspar $\quad\left[\frac{Q p}{F+L} V s \frac{Q t}{F+L}\right]$

[20] confirms that the source area paleoclimate was humid (Fig. 6). The source area rocks identified from the sandstone petrography fits the uplifted basement source. [21] used Ternary plots of framework modes (QFR) to identify provenance tectonic settings. A plot of this nature for the Abomege sandstones suggests, merger of fields for mature rocks with stable framework (Fig. 7). The resultant sands are essentially quartz arenite ([14]; [8]).

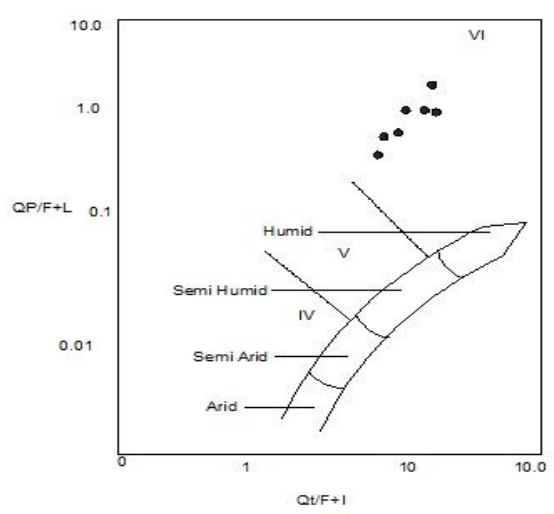

Figure 6: Tenary Plot $\mathrm{Qp} / \mathrm{F}+\mathrm{L}$ vs $\mathrm{Qt} / \mathrm{F}+\mathrm{L}$ showing that the sandstone were deposited under humid Climate ([20])

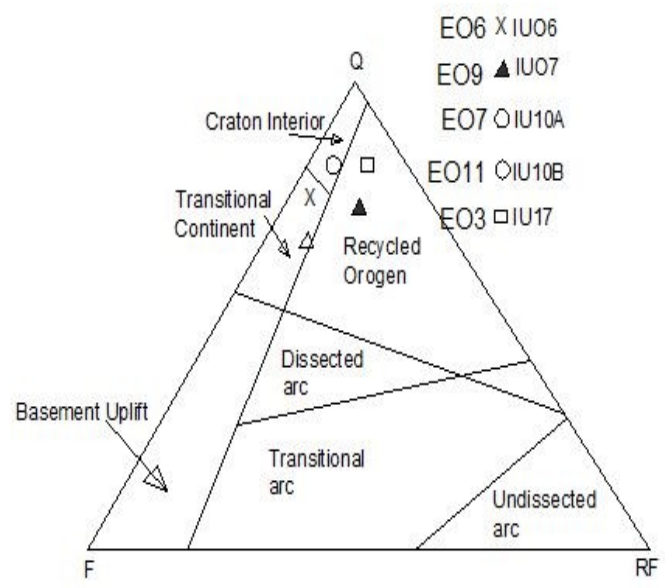

Figure 7: QRF Diagram plot for the Sandstones OF Eze-Aku Formation at Abaomege ([22]).

\section{5 Paleocurrent Analysis}

Paleocurrent measurements (Table 5) were acquired from tilted beds and restored to paleo horizontal for both cross bed dip magnitude and direction for the true paleo flow azimuth. The rose plot of cross bed azimuth directions of the Abaomege sandstones show a bimodal paleocurrent pattern (Fig. 8) with the southwest and northeast directions but dominatly in the northeast direction. Hence, the sediments were derived more from the northeast. At the Nsubba area, the rose plot shows a bimodal bipolar paleocurrent distribution. The stronger mode is to the southwest direction. The bulk of the sediment may have been derived from a provenance area located northeastern and southwestern parts of the study area. Paleocurrent analysis helps in interpreting the environment of deposition in sedimentary basins. The paleocurrent plots for the sandstones exposures in Abaomege which shows bimodal paleocurrent distribution patterns, suggests a shore environment of deposition. 
Table 4: Tally of cross- beds azimuths into $30^{\circ}$ class Intervals

\begin{tabular}{|l|l|l|l|l|}
\hline S/n & $\begin{array}{l}\text { Azimuth } \\
\text { interval }\end{array}$ & Equivalent & Frequency & $\begin{array}{l}\text { Frequency } \\
\%\end{array}$ \\
\hline 1 & $0-30$ & $181-210$ & - & - \\
\hline 2 & $31-60$ & $211-240$ & - & - \\
\hline 3 & $61-90$ & $241-170$ & 13 & 52 \\
\hline 4 & $91-120$ & $271-300$ & 12 & 48 \\
\hline 5 & $121-150$ & $301-330$ & - & - \\
\hline 6 & $151-180$ & $331-360$ & - & - \\
\hline Total & & & 25 & 100 \\
\hline
\end{tabular}

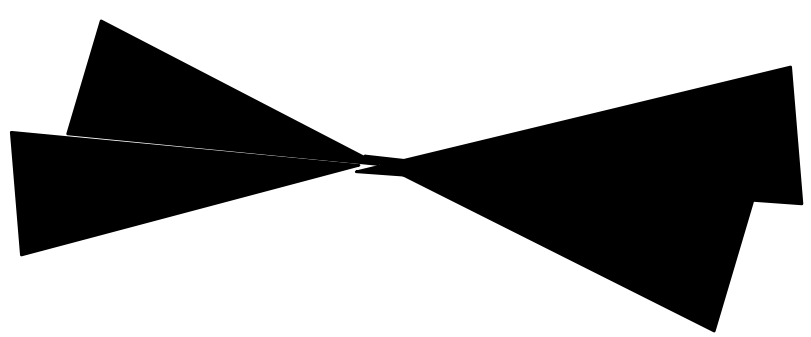

Figure 8: Paleocurrent pattern from cross beds in the sandstones of Eze-Aku Formation in Abaomege showing a Bimodal pattern.

\section{Conclusions}

The study area is underlain by fine to medium grained sandstones occurring in linear parallel ridges with subordinate shales occurring in low-lying land displaying sharp contacts. The petrography and paleocurrent analysis of the sandstones of Eze-Aku Formation in Abaomege area has shown that the sandstone is texturally immature and mineraliogically mature and are essentially quartz arenites. The paleocurrent plots for the sandstones show bimodal paleocurrent distribution patterns, suggesting a shore environment of deposition and were derived primarily from Granitic Basement Complex of the Oban Massif and Cameroon in a humid paleoclimate.

\section{References}

[1] A. Irvin, and Ion, E, A regional study of southeastern Nigeria, University of Ibadan press, Nig; 1938, 21 -26.

[2] C. M. Tattam, Review of Nigeria Stratigraphy Report of geological survey, Nigeria, 1944, 37-48

[3] R. A. Reyment, Aspects of the geology of Nigeria Ibadan university press, 1965, 145p.

[4] A. Simpson, The Nigeria coalfield. The geology of parts of Owelli and Benue Provinces, Bull. Geol, surv. Nig, 1954, No. 24, pp, $85 \mathrm{p}$.

[5] R. C. Murat, Stratigraphy and Paleogeography of the Cretaceous and L. Tertiary in southern Nigeria. In Dassauvagie, T.F. and Whiteman, A.J. (Eds). African Geol University of Ibadan press, 1972, 251-266.

[6] M. Hoque, Significance of textural and petrographic attributes of several Cretaceous Sandstones, southern Nigeria .Jounal of Geolgy. Soc. India 17, 1976, 514-521.

[7] P. E. Potter, and F. J. Pettijohn, Paleocurrent and Basin analysis, Academic press inc; New York, 1963, 294p

[8] F. J. PettiJohn, Sedimentary rocks ( $3^{\text {rd }}$ Ed.) Harper and Row New York, 1975, 195-246, 261-289.

[9] I. Banerjee, A subtidal Bar model for the Eze-Aku sandstones, Nigeria. Journal of Sedimentary Geology 30, 1980, 133-147.

[10] C. R. Cratchley, and J. P. Jones, An interpretation of the geology and gravity anomalies of the Benue Valley, Nigerian. Overseas Geological Survey, geophysical paper 1, 1965, 22-24.

[11] C. O. Okogbue, and O. P. Aghamelu, Comparism of the geotechnical properties of crushed shales from southeastern Nigeria. Springer-Verlag publication. Bulletin Engineering Geology and Environment 69, 2010, 587-597.

[12] M. Hoque, Petrographic differentiation of tectonically controlled Cretaceous sedimentary cycles, southeastern, Nigeria. Journal of Sedimentary Geology 17, 1977, 235-345.

[13] M. Hoque, and C. S. Nwajide, Tectono-sedimentological evolution of an elongate intracratonic basin (aulacogen): the case of the Benue Trough of Nigeria. Journal of Mining and Geology 21, 1985, 19-26.

[14] R. L. Folk, Petrology of sedimentary rocks. Hemphill, Austin, Texas, 1974, 182p.

[15] R. L. Folk, Stage of textural maturity in sedimentary rocks, Journal of Sedimentary petrology, vol. 21, 1951, $127-131$.

[16] A. U. Okoro, Depositional history of the sandstone facies of the Nkporo Formation (Campanian-Maastrichtian) in Leru area, southeastern Nigeria, Journal of Mining geology, vol. 31, No. 2, 1995, 105-586. 